\title{
Variability of silver fir (Abies alba Mill.) progeny from the Tisovik Reserve expressed in needle traits and chloroplast microsatellite DNA
}

\author{
Ewa M. Pawlaczyk* \& Maria A. Bobowicz \\ Department of Genetics, Faculty of Biology, Adam Mickiewicz University, Umultowska 89, 61-614 Poznań, Poland \\ * corresponding author (e-mail: ewapaw@amu.edu.pl)
}

\begin{abstract}
Progeny from nineteen family lines of silver fir (Abies alba Mill.) from the Tisovik Reserve growing in an experimental plot were analyzed based on 4 chloroplast microsatellite DNA loci and 12 morphological and anatomical needle traits. The Tisovik Reserve is located in Białowieża Primeval Forest, $120 \mathrm{~km}$ north of the natural range limit of this species, and embraces a small and isolated natural population of silver fir. The aim of this study was to determine genetic variation within and between progeny lines. Analysis of phenotypic variation showed that the traits which differed most among individuals were the needle width and the distance from resin canals to vascular bundle. Those traits, which differed most between the progeny lines, were the number of endodermic cells around the vascular bund and the weight of hypodermic cells. In Tisovik progeny, we detected 107 different haplotypes. In progeny lines, we detected more haplotypes than in maternal trees, and most haplotypes did not exist in maternal trees. This may be the result of pollen influx from other silver fir stands. Progeny from Tisovik showed a higher level of variability in comparison with maternal trees.
\end{abstract}

Key words: silver fir, offspring of isolated population, genetic diversity, phenotypic diversity, chloroplast microsatellite DNA, needle traits, Białowieża Primeval Forest

\section{Introduction}

At the present time, the observed silver fir variability is the result of microevolutionary processes, which took place during the post-glacial migration of species and in populations in warm refugia where fir survived the last glaciations. Based on pollen data (Liepelt et al. 2009 after Kral 1980), isozyme studies (Konnert \& Bergmann 1995; Liepelt et al. 2009), chloroplast microsatellite DNA (Vendramin et al. 1999; Liepelt et al. 2009) and mitochondrial DNA(Liepelt et al. 2002, 2009; Gömöry et al. 2004; Ziegenhagen et al. 2005; Pawlaczyk et al. 2013), it is presently widely accepted that silver fir arrived to Poland from one refuge located in Western Europe. The authors of the studies cited above suggest that silver fir variability in Europe is relatively high and different populations of fir exhibit geographic structure of genetic variation.

European Silver Fir (Abies alba Mill.) is one of the most important trees in Central European forests.
It is a mountain tree which grows in lowlands in the northern part of its species range. In Poland, this taxon reaches the northern limit of its distribution which runs along the northern edge of the Silesian Lowlands to the northern edge of the Central Highlands, where it cuts through the Mazowiecko-Podlaska Lowlands (Gostyńska-Jakuszewska 1972; Zając \& Zając 2001). In the Mazowiecko-Podlaska Lowlands, there is a small isolated native population of silver fir called the Tisovik reserve. This population grows $120 \mathrm{~km}$ northeast of the natural distribution for fir in the Belarusian part of the Białowieża Primeval Forest. The range of silver fir has existed for the past 2,000 years, and the population in Tisovik is a likely remnant of the post-glacial migration and contraction of the silver fir distribution.

Silver fir in Białowieża Primeval Forest was discovered in 1823 by Górski (1829). He found it in Cisovka Hag, a small forest island surrounded by widespread bogs of the Dikij Nikor river. A detailed description of Tisovik reserve is given in papers by Mejnartowicz 
(1996), Korczyk et al. (1997), Korczyk (1999, 2015a, 2015b), Goncharenko \& Savitsky (2000) and Pawlaczyk et al. $(2005,2017)$. Recently, the number of silver fir trees in the Tisovik population has reached a critical value, amounting to 20 trees (Korczyk et al. 1997, $2015 \mathrm{a}, 2015 \mathrm{~b}$ ), whereas at the beginning of $19^{\text {th }}$ century, there were about several hundred trees. Therefore, in 1991, the Tisovik Reserve was included in the Belarusian National Park, and the silver fir of the Białowieża Primeval Forest was registered as a species threatened with extinction in the Belarussian Red Book (Parfenov $\&$ Savchuk 2015). These facts contribute to the thesis that the fir population will be completely extinct in the near future due to deteriorating environmental conditions. In response to this threat, the preservation of its gene resources and variability investigations are urgent. In 1995, seeds from this population were collected, and, in 1998, the experimental area (provenance experiment) was established. This cultivation was formed on the Polish side of the Białowieża Primeval Forest in the Hajnówka District, where progeny of 19 maternal trees are growing: half-sibs, known mother, unknown father. Provenance and test-culture experiments are being carried out in order to eliminate or, at least, reduce the environmental impact on the observed variability. This has a special importance for the selection of a group of trees for renewal of the forest (Wright 1976). Thus, in this paper, we describe trees that are offspring of a small and isolated population of silver fir growing in balanced environmental conditions in an experimental plot.

Consequently, the main aim of our study is to describe the within and among open-pollinated family variation of silver fir from the Tisovik reserve at two levels: phenotypic - by analysis of the morphological and anatomical needle traits, and genetic - using molecular markers (chloroplast microsatellite DNA - cpSSR).

Phenotypic variation might be related to processes of adaptation and microsatellite markers are useful to study the demography and may indicate possible reduction of mates mating with each female tree. It is possible, because chloroplast genome is inherited by paternal lineage and there is lack of recombination (Neale \& Sederoff 1989; Vendramin \& Ziegenhagen 1997).

Detected variation should provide background for understanding the process of adaptation to marginal conditions prevailing at the border of species distribution and will help trace trends and microevolutionary processes, which occur in small and isolated populations. Understanding the variability of the Tisovik offspring may be useful for the renewal of this stand and may verify the thesis of the low level of differentiation in this population. Besides, Tisovik population is interesting as a remnant population which might be subjected to local microevolutionary forces as genetic drift.

\section{Materials and methods}

\subsection{Study site}

In order to protect the gene pool and detect genetic variation in silver fir from the Tisovik Reserve, a provenance-progeny experimental plot was established by Professor A. F. Korczyk from the Forest Research Institute in Białowieża and Białystok University of Technology. In 1995, seeds from 20 silver fir trees were collected and sowed in a forest nursery in Nawojowa (Beskid Sądecki). The seeds of progeny lines were collected from respective mother trees and properly marked. Next, in 1998 three-year-old marked seedlings were moved to an experimental plot in Hajnówka Forest District (Leśna, Wilczy Jar, section 416Ag/416Cf). The area of silviculture is about 0.225 ha (Poland). The detailed description about establishing the plot and cultivation of fir is given in a paper by Korczyk (2015b).

Plant material (needles and buds) was collected in 2010 from properly marked 19 lines of progeny in the

Table 1. The list of studied morphological and anatomical needle traits of Abies alba

\begin{tabular}{cl}
\hline Number of trait & \multicolumn{1}{c}{ Name of trait } \\
\hline 1 & needle length \\
2 & diameter of resin canals \\
3 & needle width measured in cross section \\
4 & needle height measured in cross section \\
5 & hypodermic cell height \\
6 & hypodermic cell width \\
7 & number of endodermic cells around vascular bundle \\
8 & distance from vascular bundle to abaxial needle edge \\
9 & distance from resin canals to needle edge \\
10 & distance from resin canals to vascular bundle \\
11 & shape of needle: height-to-width ratio (traits 4/3) \\
12 & shape of hypodermic cell: width-to-height ratio (traits 6/5) \\
\hline
\end{tabular}


Table 2. Characteristic of used primers ( $\mathrm{T}$ - temperature of annealing)

\begin{tabular}{|c|c|c|c|c|}
\hline Primer & Motive & Allele size (bp) & Primer Sequence & $\mathrm{T}\left[{ }^{\circ} \mathrm{C}\right]$ \\
\hline РCP 71987* & $(\mathrm{T})_{16}$ & $94-97$ & $\begin{array}{l}\text { 5'-CACAAAAGGATTTTTTTTCAGTG-3' } \\
\text { 5'-CGACGTGAGTAAGAATGGTTG-3' }\end{array}$ & $54^{\circ} \mathrm{C}$ \\
\hline РСР 30277* & $(A)_{12}(G)_{10}$ & $107-114$ & $\begin{array}{l}\text { 5'-TCTTTGCAAGAAGGATGGCT-3' } \\
\text { 5'-GGGGAGTAATCCGTGGAATT-3' }\end{array}$ & $54^{\circ} \mathrm{C}$ \\
\hline Pt 30204** & $\begin{array}{l}(\mathrm{A})_{10}(\mathrm{G})_{12^{-}} \\
(\mathrm{A})_{8}(\mathrm{G})_{9}\end{array}$ & $130-145$ & $\begin{array}{l}\text { 5'-TCATAGCGGAAGATCCTCTTT-3' } \\
\text { 5'-CGGAATTGATCCTAACCATACC-3' }\end{array}$ & $54^{\circ} \mathrm{C}$ \\
\hline Pt $71936^{* *}$ & $(\mathrm{~T})_{14}-(\mathrm{T})_{16}$ & $130-150$ & $\begin{array}{l}\text { 5'-TTCATTGGAAATACACTAGCCC-3' } \\
\text { 5'-AAAACCGTACATGAGATTCCC-3' }\end{array}$ & $54^{\circ} \mathrm{C}$ \\
\hline
\end{tabular}

Explanations: * - primers from Provan et al. (1998), ** - primers from Vendramin et al. (1996)

cultivation area of Hajnówka District (Poland) from fifteen-year-old progeny and relative 19 maternal trees from the Tisovik Reserve (Belarus). Each progeny line was represented by 8 to 15 trees. The total of 274 progeny trees and 19 maternal trees were studied. For morphological analysis, one-year-old needles were collected and, after collection, needles were marked and placed in tubes and preserved in $70 \%$ ethanol. For molecular studies, the buds were collected and stored in a freezer at the temperature of $-20^{\circ} \mathrm{C}$ until the beginning of analysis.

\subsection{Analysis of needle traits}

From each tree, ten needles were used to make slides (cross section of needles). In total, 2930 needles were analyzed and 12 morphological and anatomical traits were measured. The list of measured traits is given in Table 1.

The first trait (needle length) was measured with graph paper, and the others with the use of a light microscope. Traits 3 and 4 were measured under $4 \times$ magnification, and traits 2, 5, 6, 8, 9 and 10 - under $40 \times$ magnification using a microscope, camera and measurement program from the Olympus Corporation.

These studied traits were previously tested and shown to clearly distinguish individuals, progeny and populations of silver fir (Pawlaczyk et al. 2002, 2005, 2010; Pawlaczyk \& Bobowicz 2008a, 2008b).

\subsection{Molecular analysis}

Genomic DNA was extracted from fir needles and bud tissue. Frozen needles and buds (100 mg of tissue) were powdered in liquid nitrogen and the total genomic DNA was extracted using a modified ATMAB method (Doyle \& Doyle 1990), and dissolved in $0.1 \times$ TE buffer (10 mM pH 8.0 Tris-HCl; $1 \mathrm{mM} \mathrm{pH} \mathrm{8.0} \mathrm{EDTA)} \mathrm{for}$ subsequent use. The quality and quantity of the extracted DNA were measured on a Nanodrop ${ }^{\mathrm{TM}}$ ND-1000 (ThermoScientific) spectrophotometer and diluted to a final concentration of $20 \mathrm{ng} / \mu \mathrm{l}$.

\section{4. cpSSR amplification}

In this paper, the research was conducted on the basis of chloroplast microsatellite DNA polymorphism analysis. The universal character and high variability of cpSSR markers was confirmed for many coniferous species. Moreover, cpSSR markers were used because seeds were collected from particular mothers and were not mixed (high confidence of the maternity of progenies). Besides, these markers may provide information on paternity, and with high diversity of cpSSR haplotypes, they might inform about the number of fathers contributing to progeny lines. The cpSSR markers were also used in studies of population structure, gene flow, and demographic history of populations (Morgante et al. 1997; Echt et al. 1998; Provan et al. 1998; Vendramin et al. 1999; Clark et al. 2000; Semerikova \& Semerikov 2007; Dzialuk et al. 2009).

The possibility of amplification and the level of polymorphism for 8 primer pairs of chloroplast microsatellite loci selected from the published literature were checked initially: PCP 71987, PCP 30277, Pt 30204, Pt 71936, PCP 45071, Pt 45002, PCP 1289, PCP 41131 (Vendramin et al. 1996; Provan et al. 1998). However, some of these markers were either monomorphic or did not give an amplification of products, or showed unstable amplification. Finally, four markers: PCP 71987, PCP 30277, Pt 30204 and Pt 71936, which gave satisfactory stable amplification products were classified as variable and were used for analyses (Table 2).

Polymerase chain reaction (PCR) amplifications were performed in a 2720 Thermal Cycler (Applied Biosytems). Each amplification reaction contained $1 \times$ reaction buffer (Novazym), $0.2 \mathrm{mM}$ each dNTP, 0.25 $\mu \mathrm{M}$ forward and reverse primer and $0.5 \mathrm{U}$ HiFiTaq DNA polymerase (Novazym), approximately $50 \mathrm{ng}$ genomic DNA and deionized water to a total volume of $10 \mu$. The forward primer of each primer pair was fluorescent labeled with 6FAM and VIC dye (Applied Biosystems) at its 5 'end. amplifications were carried out separately for each marker and the following PCR temperature 



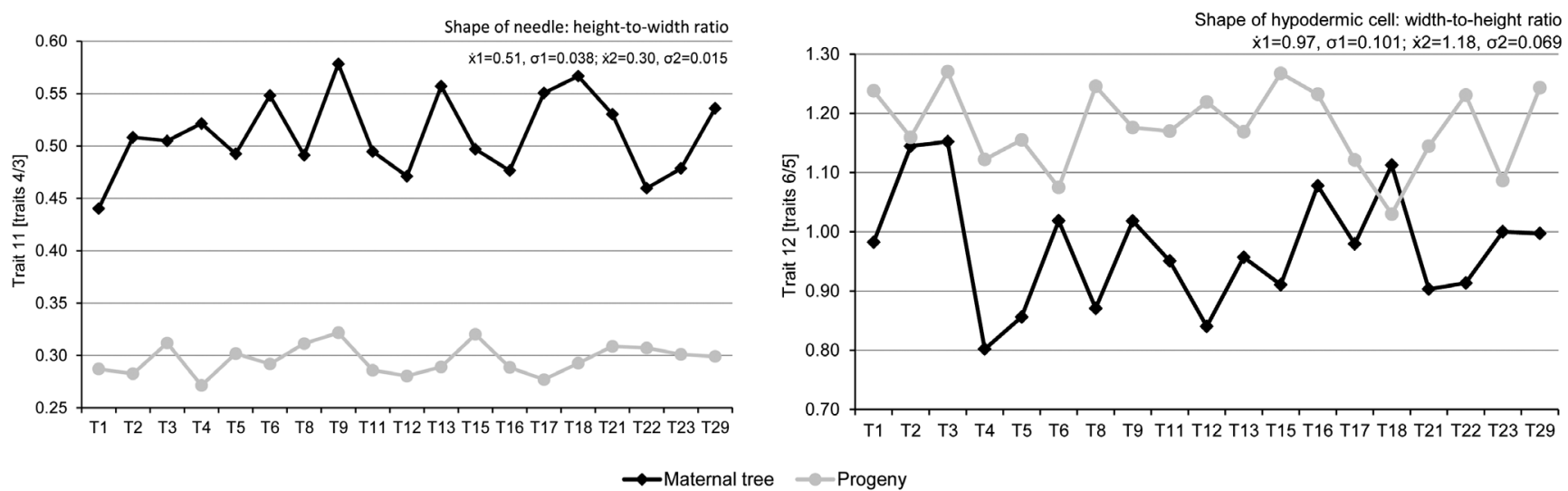

Fig. 1. The graph of arithmetic mean for 12 traits in individual maternal tree and progeny line of Abies alba

profile was used: initial denaturation at $94^{\circ} \mathrm{C}$ for $5 \mathrm{mins}$, 35 cycles of $94^{\circ} \mathrm{C}$ for $1 \mathrm{~min}, 54^{\circ} \mathrm{C}$ for $1 \mathrm{~min}, 72^{\circ} \mathrm{C}$ for $1 \mathrm{~min}$, with a final elongation step at $72^{\circ} \mathrm{C}$ for 10 mins. PCR products were separated with a 3130xl Genetic Analyzer (Applied Biosystems) capillary electrophoresis system with a GeneScan ${ }^{\mathrm{TM}} 600 \mathrm{LIZ}^{\mathrm{TM}}$ as an internal size standard. Individuals were analyzed and genotyped using GeneMapper version 3.7 software (Applied Biosystems).

\subsection{Statistical methods}

The data for 12 morphological and anatomical traits of needles were analyzed with Statistica ver. 10 (StatSoft Inc.) on the intra and inter family level. The analyses were based on trait characteristics, correlation coefficients, Student's t-test, analysis of variance (ANOVA, MANOVA), discriminant analysis with Mahalanobis distances between progeny, and agglomerant grouping by the nearest neighborhood method on the basis of Mahalanobis distances (dendrogram).

The genetic diversity was estimated on the basis of haplotypes. Each individual chloroplast haplotype was defined as a unique combination of size variants across the microsatellite regions within an individual.

For each progeny line, the effective number of haplotypes, the frequency of private haplotypes, the haplotype diversity and Nei genetic distance (Nei 1972; Vendramin et al. 1999) were calculated using the program GenAlEx (Peakall \& Smouse 2006). Based on Nei distances (PopGene version 1.31 program, Yeh et al. 1999), a UPGMA dendrogram was constructed (MEGA 7 software). Additionally, genetic distances between detected haplotypes were calculated (GenAlEx program, Peakall \& Smouse 2006) and then the UPGMA dendrogram was drawn (MEGA 7 software).

Genetic differentiation among progeny lines was estimated by hierarchical analysis of molecular variance (AMOVA) calculated using GenAIEx v.6.4 software
(Excoffier et al. 2005). Statistical significance was determined by random permutation, with the number of permutations set to 999 .

\section{Results}

\subsection{Analysis of needle traits in the progeny}

Analysis of the arithmetic mean of particular traits was given in Figure 1. In order to determine which traits most differentiated the studied progeny, an analysis of variance was conducted and the F statistic was calculated (Fig. 2). Calculations showed that the features which most varied among progeny were: width of hypodermic cell (6), number of endodermic cells (7) and distance from vascular bundle to abaxial needle edge (8). The least significant were the width of the needle (3) and the length of the needle (1).

Analysis of variance was performed to check which traits differed between individuals within progeny lines (in documentation of the work). So, seedlings in progeny lines: T1, T2, T3, T6, T8, T11, T12, T13, T16, T17, T18, T22 and T23 differed the most in terms of the width of the needle (3), in progeny lines: T5, T15 and T21 - it was the length of the needle (1), and in T4 and T29 - the height of the needle (4). These three traits differentiated individuals the most in every progeny line. Individuals in all progeny lines differed least in terms of the height (5) and the width (6) of hypodermic cell, number of endodermic cells (7) and shape of hypodermic cell (12). In progeny lines T5, T8, T9 and $\mathrm{T} 16$, this factor was the distance from vascular bundle to abaxial needle edge (8) and in progeny T17 and T22 - it was the distance from resin canals to needle edge (9).

In order to determine which progeny lines were the most differentiated with respect to all 12 needle traits, the Wilks' Lambda in MANOVA was calculated (Table $3)$. This parameter indicated that the greatest diversity 


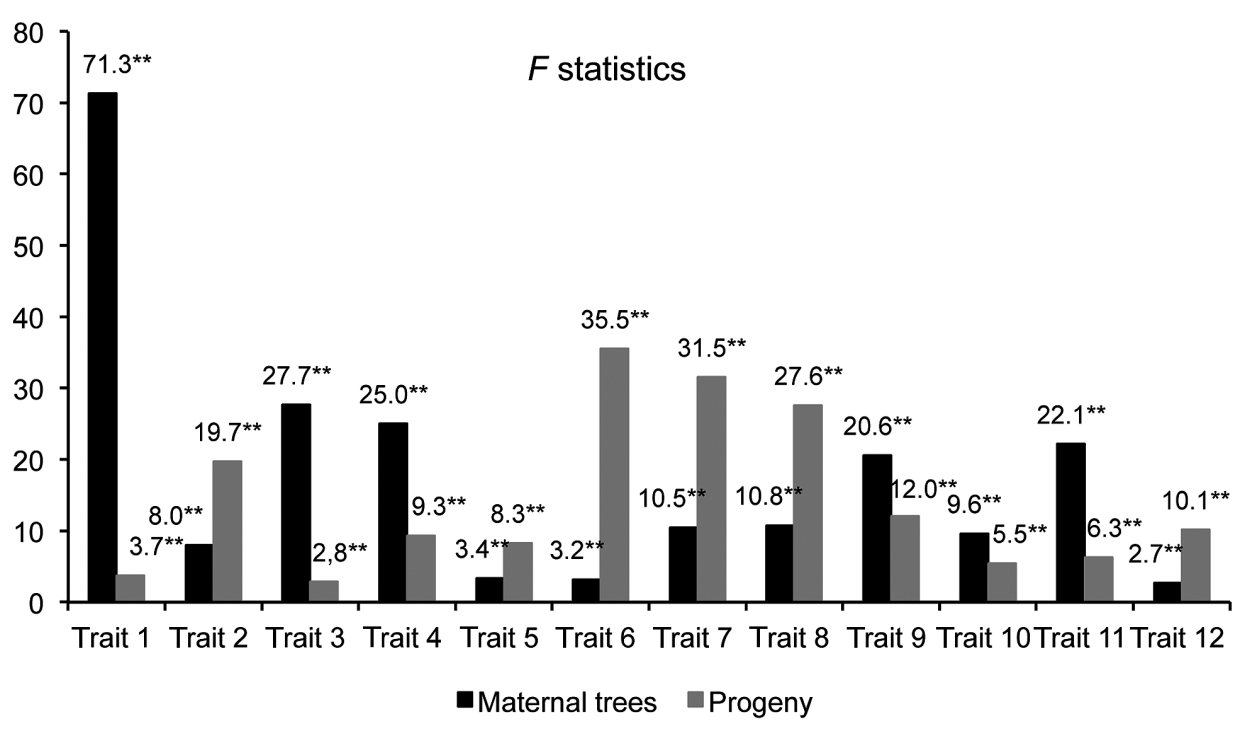

Fig. 2. F statistics between the studied maternal trees and progeny lines of Abies alba

occurred in progeny row T1 $(0.000077)$, and the lowest - in T4 (0.002502).

Based on the table of calculated Mahalanobis distances (in the documentation of the work) between progeny, it can be concluded that out of 171 distances, only 2 were not statistically significant, 9 were statistically significant at $\alpha=0.05$, and 160 were highly statistically

Table 3. Wilks' Lambda from MANOVA calculated within progeny lines and for maternal trees of Abies alba

\begin{tabular}{cccc}
\hline Progeny line & $N$ & Lambda Wilksa & $p$ \\
\hline T1 & 140 & 0.000077 & $* * *$ \\
T2 & 150 & 0.000156 & $* * *$ \\
T3 & 150 & 0.000143 & $* * *$ \\
T4 & 150 & 0.002502 & $* * *$ \\
T5 & 150 & 0.001039 & $* * *$ \\
T6 & 150 & 0.001001 & $* * *$ \\
T8 & 140 & 0.000334 & $* * *$ \\
T9 & 150 & 0.000258 & $* * *$ \\
T11 & 150 & 0.000183 & $* * *$ \\
T12 & 150 & 0.000160 & $* * *$ \\
T13 & 150 & 0.000331 & $* * *$ \\
T15 & 150 & 0.001069 & $* * *$ \\
T16 & 150 & 0.000316 & $* * *$ \\
T17 & 150 & 0.001572 & $* * *$ \\
T18 & 150 & 0.000160 & $* * *$ \\
T21 & 130 & 0.000427 & $* * *$ \\
T22 & 150 & 0.000955 & $* * *$ \\
T23 & 80 & 0.000487 & $* * *$ \\
T29 & 150 & 0.000527 & $* * *$ \\
Average & 144.2 & 0.000615 & $* * *$ \\
Total & 274 & 0.000940 & $* * *$ \\
& 2740 & 0.021861 & $* * *$ \\
Maternal trees & 190 & 0.000615 & $* * *$ \\
\hline
\end{tabular}

Explanation: $* * *$ - value significant at $\alpha=0.001$ significant at $\alpha=0.01$. The largest Mahalanobis distances existed between $\mathrm{T} 1$ and $\mathrm{T} 15(\mathrm{D}=9.37)$ and $\mathrm{T} 1$ and $\mathrm{T} 9$ $(\mathrm{D}=9.23)$, and the smallest - between $\mathrm{T} 8$ and $\mathrm{T} 22$ $(\mathrm{D}=1.68)$, and $\mathrm{T} 12$ and $\mathrm{T} 16(\mathrm{D}=1.74)$. A dendrogram (Fig. 3a) constructed based on Mahalanobis distances showed that progeny lines formed two groups with subgroups. The first group with: T17, T2, T21, T23, T6, T9, T15 and T3 progeny lines formed two sub-groups. The second group was divided into 3 subgroups: T1, T8 and T22 (first subgroup), T29, T 13, T16 and T12 (second subgroup) and T18, T11, T5 and T4 (third subgroup).

The existence of internal structure of these progeny is confirmed by the graph of discriminant analysis (Fig. 4). The progeny lines formed four subgroups. On the basis of determination coefficients (Table 4) between the 12 needle traits and between the first three discriminant variables $\left(\mathrm{U}_{1}, \mathrm{U}_{2}\right.$ and $\left.\mathrm{U}_{3}\right)$, variability

Table 4. The determination coefficients between the studied needle traits of Abies alba and first three discriminant variables

\begin{tabular}{cccc}
\hline Trait & $\mathrm{U}_{1} 52.28 \%$ & $\mathrm{U}_{2} 20.23 \%$ & $\mathrm{U}_{3} 14.21 \%$ \\
\hline 1 & 0.1153 & 0.6245 & 0.0342 \\
2 & 3.5756 & 1.0870 & 4.0250 \\
3 & 0.0083 & 0.1499 & 0.6473 \\
4 & 0.1526 & 1.6559 & 3.9564 \\
5 & 0.6241 & 0.1166 & 0.0462 \\
6 & 6.4215 & 0.0664 & 0.9017 \\
7 & 2.4593 & 9.3567 & 0.1265 \\
8 & 7.1627 & 0.1890 & 0.5246 \\
9 & 5.0008 & 0.5734 & 2.1518 \\
10 & 1.2318 & 0.1292 & 0.7639 \\
11 & 0.2403 & 0.8870 & 1.8225 \\
12 & 0.1390 & 0.8743 & 0.0328 \\
\hline
\end{tabular}




\section{Progeny}
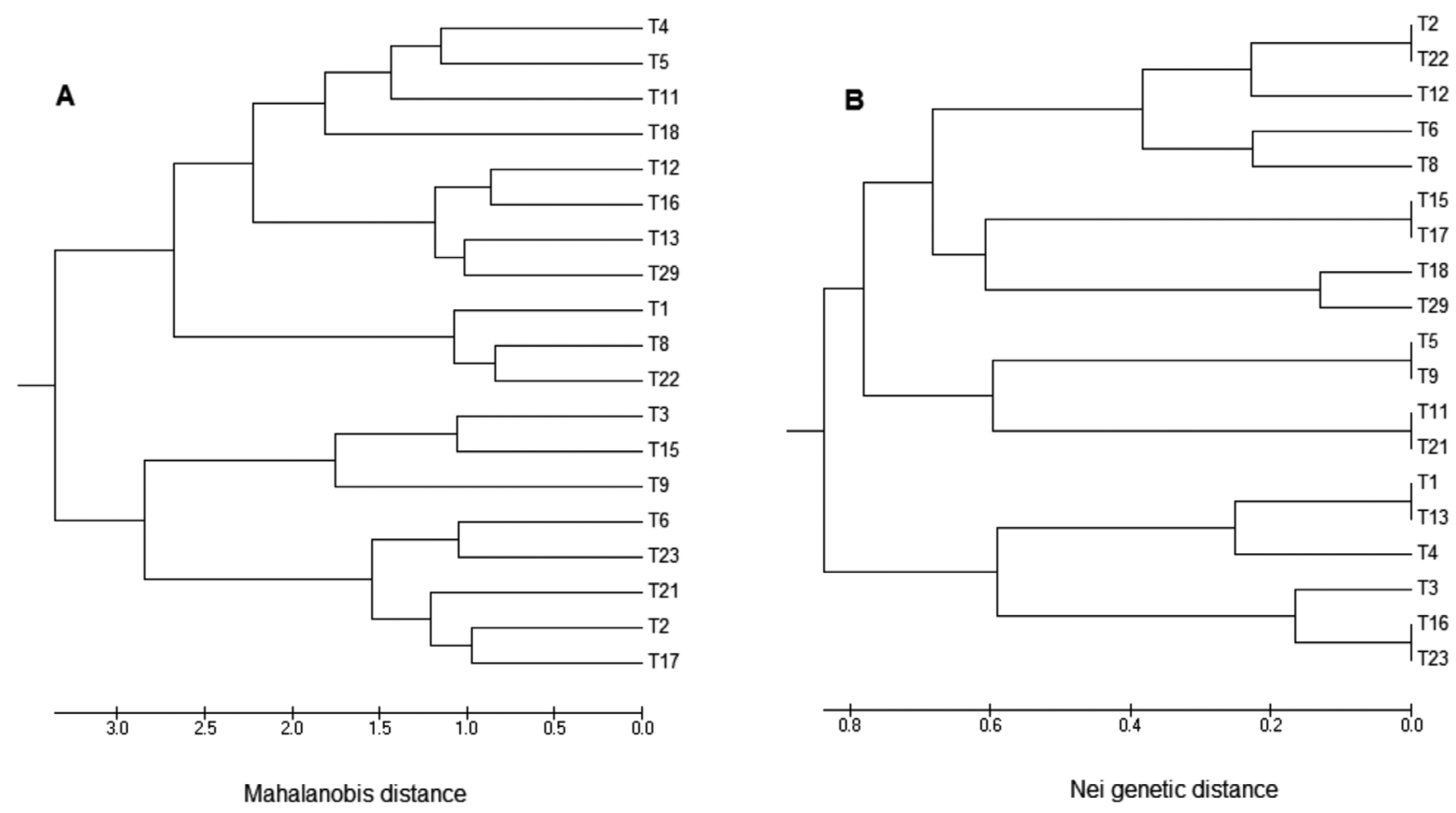

Fig. 3. UPGMA dendrograms for progeny lines based on (A) Mahalanobis distances calculated from morphological and anatomical needles traits of Abies alba and (B) Nei's genetic distances calculated from cpSSR data

was found. The distance from the vascular bundle to abaxial needle edge (8) and hypodermic cell width (6) were the traits with the greatest influence on $U_{1}$. The number of endodermic cells around vascular bundle (7) had the greatest influence on $\mathrm{U}_{2}$, whereas diameter of resin canals (2) and needle height (4) - on $\mathrm{U}_{3}$. Third discriminant variable $\mathrm{U}_{3}$ caused the distinctiveness of subgroup with progeny lines: T11, T12, T13, T16 and T29. These progeny lines had the widest resin canals but the shortest needles.

\section{Progeny}

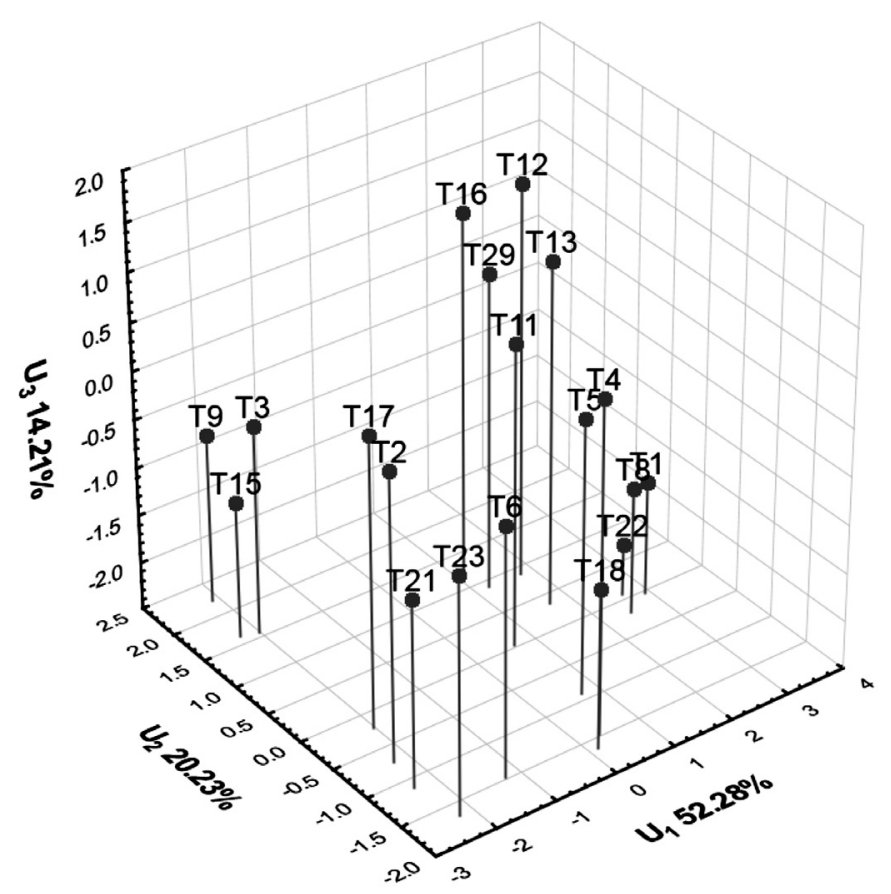

Fig. 4. Results of discriminant analysis of Abies alba progeny lines from the Tisovik Reserve population, in the space of the first three discriminant variables $\left(\mathrm{U}_{1}, \mathrm{U}_{2}\right.$ and $\left.\mathrm{U}_{3}\right)$, accounting for $86.72 \%$ of the variability of morphological and anatomical traits of needles 


\subsection{Molecular analysis}

The total of 107 different haplotypes was identified. All haplotypes had a frequency below 0.06 , as averaged over the total set of 274 trees (Appendix 1). The most abundant haplotype 95/109/133/144 was found in 17 trees from ten different progeny lines. The number of haplotypes per population varied from 7 to 14 and the efective number of haplotypes from 5.8 to 14.0 , with haplotype diversity from 0.886 to 1.0 ; the ratio of the number of haplotypes in progeny to sample size was from 60.0 to $100 \%$ (in T1 progeny line with sample size equal to number of haplotypes). The lowest variability was observed in progeny lines T29, T3, T4 and T9 $(0.886 ; 0.905 ; 0.905 ; 0.914$ respectively) and the highest was found in progeny lines $\mathrm{T} 1\left(H_{H}=1.00\right)$ and T5 $\left(H_{H}=0.99\right)$. All progeny lines had private haplotypes. The highest number of private haplotypes was found in progeny line $\mathrm{T} 1$ (11 private haplotypes) and the lowest in T8, T18 and T29 (1 private haplotype). The majority of haplotypes (78) were detected only once $(85.3 \%$ of progeny-private haplotypes) (Table 5).

Analysis of molecular variance (AMOVA) for haplotypic patterns showed that all of the discovered variance was present within progeny lines $\left(\Phi_{\mathrm{PT}}=0.004 ; P=0.536\right)$ (Table 6).

On the basis of the calculated Nei' genetic distances using the UPGMA method, a dendrogram was constructed (Fig. 3b). The progeny formed two groups: the first - with the progeny of T1, T13, T4, T3, T16 and $\mathrm{T} 23$, and the second - with the remaining progeny. The progeny lines which created the second group were divided into two subgroups (the first with T5, T9, T11 and $\mathrm{T} 21$, and the second with T15, T17, T18, T29 and T2, T22, T12, T6, T8).

Additionally, the dendrogram was constructed for 107 haplotypes (Fig. 5). The haplotypes created two main groups, but all detected maternal haplotypes were in one group.

\subsection{Comparison of progeny to maternal trees: analysis of needle traits}

Analysis of the variability of maternal trees on the basis of 12 needle traits was described by Pawlaczyk et al. (2005). Comparison of the arithmetic means of maternal trees and their progeny (Fig. 1) showed that the offspring exhibited larger values for five characteristics: the length of needles (1), the width of the hypodermic cell (6), the number of endodermic cells (7), distance from resin canals to vascular bundle (10) and shape of hypodermic cell (12). In other traits, maternal trees had higher values than progeny.

F statistics (Fig. 2) showed that the features that varied most between individuals forming maternal trees were: length (1), height (4), width (3) and shape

Fig. 5. UPGMA dendrogram of detected haplotypes in the progeny lines of Abies alba (in circles - haplotypes detected in maternal trees)

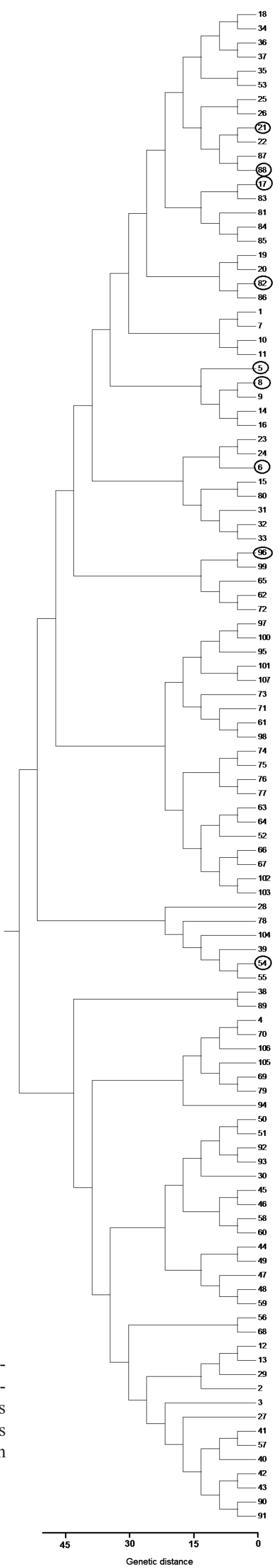


Table 5. Genetic diversity indices calculated based on the frequencies of detected haplotypes and alleles of Abies alba

\begin{tabular}{crrrrrr}
\hline Progeny line & $N$ & $N_{H}$ & \multicolumn{1}{c}{$N_{E H}$} & $N_{P H}$ & $N o / n \%$ & $H_{H}$ \\
\hline T1 & 14 & 14 & 14.000 & 11 & 100.00 & 1.000 \\
T2 & 15 & 13 & 11.842 & 7 & 86.67 & 0.981 \\
T3 & 15 & 9 & 6.429 & 2 & 60.00 & 0.905 \\
T4 & 15 & 9 & 6.429 & 3 & 60.00 & 0.905 \\
T5 & 15 & 14 & 13.235 & 7 & 93.33 & 0.990 \\
T6 & 15 & 12 & 9.783 & 6 & 80.00 & 0.962 \\
T8 & 14 & 12 & 10.889 & 1 & 85.71 & 0.978 \\
T9 & 15 & 9 & 6.818 & 4 & 60.00 & 0.914 \\
T11 & 15 & 10 & 7.258 & 3 & 66.67 & 0.924 \\
T12 & 15 & 11 & 9.783 & 2 & 73.33 & 0.962 \\
T13 & 15 & 14 & 13.235 & 6 & 93.33 & 0.990 \\
T15 & 15 & 11 & 7.759 & 7 & 73.33 & 0.933 \\
T16 & 15 & 12 & 10.714 & 3 & 80.00 & 0.971 \\
T17 & 15 & 13 & 11.842 & 4 & 86.67 & 0.981 \\
T18 & 15 & 11 & 8.333 & 1 & 73.33 & 0.943 \\
T21 & 13 & 10 & 8.895 & 3 & 76.92 & 0.962 \\
T22 & 15 & 11 & 8.333 & 4 & 73.33 & 0.943 \\
T23 & 8 & 7 & 7.000 & 3 & 87.50 & 0.993 \\
T29 & 15 & 9 & 5.769 & 1 & 60.00 & 0.886 \\
Average & 14.42 & 11.11 & 9.387 & 4.105 & 77.37 & 0.954 \\
Total & 274 & 107 & & 78 & & \\
Maternal trees & 19 & 14 & 8.805 & & 73.68 & 0.936 \\
\hline
\end{tabular}

Explanations: $N$ - sample size, $N_{H}$ - number of hyplotypes, $N_{E H}$ - number of effective haplotypes, $N_{P H}$ - number of private haplotypes, $N o / n \%$ - the ratio of the number of haplotypes to sample size, $H_{H}$ - haplotype diversity

(11) of needle. The least different were the width (6) and height (5) of hypodermic cells.

Pearson correlation coefficients calculated between offspring and maternal trees indicated a low correlation of traits (Table 7). Five traits were correlated negatively: the length of the needle (1), the height of the needle (4), the width of the hypodermic cell (6), distance from vascular bundle to abaxial needle edge (8) and shape of hypodermic cell (12). The highest positive value of the correlation coefficient was detected for the distance from resin canals to vascular bundle (10), and this ratio was statistically significant at the level of $\alpha=0.05$.

In order to determine the significance of differences between the arithmetic means of progeny and their maternal trees, the Student's t-test was calculated (Table
7). On this basis, it can be concluded that maternal trees and progeny most differed in terms of: the height of the needle (4), the shape of the needle (11), distance from vascular bundle to abaxial needle edge (8) and distance from resin canals to vascular bundle (10) at the level of significance of $\alpha=0.01$. The traits least significant for differentiating progeny lines from their maternal trees were: the height of the hypodermic cell (5) and diameter of resin canals (2).

\subsection{Comparison of progeny to maternal trees: molecular analysis}

In maternal trees, fourteen different haplotypes were identified on 19 studied trees (Table 8). The most abundant haplotype (No 21) was found in 5 trees. The number of effective haplotypes was 8.805 and haplotype

Table 6. Analysis of molecular variance (AMOVA) based on the detected haplotypes of Abies alba

\begin{tabular}{lrrrcccc}
\hline Source of variance & \multicolumn{1}{c}{$d f$} & \multicolumn{1}{c}{$S S D$} & MSD & Variance component & \% of total variance & $\Phi_{P T}$ & $p$ \\
Among progeny & 18 & 12913.9 & 717.4 & 0.0 & 0 & 0.004 & 0.536 \\
Within progeny & 255 & 194890.8 & 764.3 & 764.3 & 100 & 100 & \\
Total & 273 & 207804.7 & & 764.3 & & \\
\hline
\end{tabular}


Table 7. The comparison means of needle traits between maternal trees and progeny of Abies alba based on the Student's $t$-test and Pearson correlation coefficient $(r)$

\begin{tabular}{ccccc}
\hline Trait & Maternal trees & Progeny & t-value & r-value \\
\hline 1 & 17.0000 & 24.7661 & $-11.68^{* * *}$ & -0.34 \\
2 & 0.1222 & 0.1096 & $2.69 *$ & 0.32 \\
3 & 2.1338 & 1.9539 & $5.39 * * *$ & 0.04 \\
4 & 1.0877 & 0.5777 & $22.83^{* * *}$ & -0.09 \\
5 & 0.0216 & 0.0183 & $2.76^{* *}$ & 0.36 \\
6 & 0.0206 & 0.0208 & $-0.12 \mathrm{~ns}$ & -0.08 \\
7 & 25.6579 & 30.6486 & $-4.36^{* * *}$ & 0.07 \\
8 & 0.3100 & 0.1223 & $19.03^{* * *}$ & -0.18 \\
9 & 0.2256 & 0.1578 & $7.83^{* * *}$ & 0.24 \\
10 & 0.3348 & 0.4832 & $-14.00^{* * *}$ & $0.51 *$ \\
11 & 0.5107 & 0.2963 & $22.75^{* * *}$ & 0.05 \\
12 & 0.9731 & 1.1767 & $-7.28^{* * *}$ & -0.11 \\
\hline
\end{tabular}

Explanations: * - value significant at $\alpha=0.05, * *$ - value significant at $\alpha=0.01, * * *$ - value significant at $\alpha=0.001$, ns - not significant

diversity $\left(H_{H}\right)$ was 0.936 , and the ratio of number of haplotypes to sample size was 0.7368 (Table 5).

Tables 5 and 9 give the list of haplotypes and their frequencies for progeny lines and maternal trees. Nine (from 14) maternal haplotypes were detected in the progeny. Haplotypes No. 21 (95/109/133/144) and 17 $(95 / 109 / 132 / 144)$ had the highest frequency in progeny.

\section{Discussion}

\subsection{Phenotypic analysis}

A typical needle of species from the family Pinaceae is a long-term organ showing many adaptations to the living environment stand, for example, through strongly reduced surface evaporation, a thick layer of the cuticle or stomata placed in cavities of the epidermis. The study of needles is one of the easiest ways to assess the state of health of trees (Kozlov \& Nemela 1999; Innes \& Skelly 2002; Błocka \& Staszewski 2007; Klánowá et al. 2009; Chudzińska et al. 2014, 2016).

In terms of the morphology and anatomy of needle traits, this population was examined by Pawlaczyk et al. (2005). Those studies showed a poor intrapopulational diversity of trees. Features which varied most between individuals were: the length, height, width and shape of the needle.

The offspring of Tisovik from the experimental plot in the Forest District in Hajnówka was examined

Table 8. The list of detected haplotypes in maternal trees of Abies alba

\begin{tabular}{cccccc}
\hline $\begin{array}{c}\text { Order Number } \\
\text { according to } \\
\text { progeny }\end{array}$ & Haplotype & Number & Maternal tree & $\begin{array}{c}\text { Frequency in } \\
\text { maternal trees }\end{array}$ & $\begin{array}{c}\text { Frequency in } \\
\text { progeny }\end{array}$ \\
\hline A & $94 / 108 / 132 / 143$ & 1 & $\mathrm{~T} 3$ & 0.053 & 0 \\
$\mathrm{~B}$ & $95 / 106 / 130 / 139$ & 1 & $\mathrm{~T} 16$ & 0.053 & 0 \\
5 & $95 / 107 / 130 / 145$ & 1 & $\mathrm{~T} 1$ & 0.053 & 0.0036 \\
6 & $95 / 107 / 132 / 148$ & 1 & $\mathrm{~T} 23$ & 0.053 & 0.0036 \\
$\mathrm{C}$ & $95 / 108 / 130 / 141$ & 1 & $\mathrm{~T} 18$ & 0.053 & 0 \\
$\mathrm{D}$ & $95 / 108 / 130 / 142$ & 2 & $\mathrm{~T} 5, \mathrm{~T} 11$ & 0.105 & 0 \\
8 & $95 / 108 / 131 / 143$ & 1 & $\mathrm{~T} 2$ & 0.053 & 0.011 \\
17 & $95 / 109 / 132 / 144$ & 1 & $\mathrm{~T} 4$ & 0.053 & 0.051 \\
21 & $95 / 109 / 133 / 144$ & 5 & $\mathrm{~T} 6, \mathrm{~T} 8, \mathrm{~T} 13, \mathrm{~T} 21, \mathrm{~T} 22$ & 0.260 & 0.062 \\
54 & $95 / 111 / 135 / 146$ & 1 & $\mathrm{~T} 29$ & 0.053 & 0.0036 \\
$\mathrm{E}$ & $96 / 108 / 132 / 143$ & 1 & $\mathrm{~T} 17$ & 0.053 & 0 \\
82 & $96 / 109 / 132 / 143$ & 1 & $\mathrm{~T} 15$ & 0.053 & 0.0036 \\
83 & $96 / 109 / 132 / 144$ & 1 & $\mathrm{~T} 9$ & 0.053 & 0.0036 \\
96 & $96 / 112 / 130 / 143$ & 1 & $\mathrm{~T} 12$ & 0.053 & 0.0036 \\
\hline
\end{tabular}

Explanations: A-E - acronyms of haplotypes that were not found in progeny 
in terms of the morphology and anatomy of needles by Szymańska (2007). Individuals which were studied were seven years old. Intra-progeny analysis revealed presence of highly significant differences between individuals, and features that most differentiated trees within progeny lines were: the width of the needle and distance from resin canals to needle edge. Inter progeny analysis revealed presence of significant differences between progeny lines and traits, which most differentiated progeny were: the number of endodermic cells and the distance from resin canals to needle edge. Those studies did not confirm opinions about the high level of inbreeding (small genetic differentiation) apparent in this silver fir. Moreover, Szymańska's study showed good health and breeding condition for progeny of this unique population. The detected high genetic diversity of progeny from Tisovik provided evidence of a good level of adaptation to local conditions.

In this paper, 15-year-old offspring of 19 maternal trees were studied. The purpose of such a repetition was to check whether the high level of variability observed by Szymańska (2007) was maintained, or whether it may have been characteristic only in the first phase of the development of fir trees.

In the present work, analyses made within progeny showed that the width of needles was one feature which most differentiated individuals (14 progeny lines). In addition, the length of the needle ( 3 progeny lines) and the height of the needle ( 2 progeny lines). The features having the least impact on the formation of intra-progeny variability were the height and width of the hypodermic cell, number of endodermic cells and shape of hypodermic cell.

The same traits: shape of hypodermic cell, width and height of hypodermic cell were found to least differentiate maternal trees from Tisovik (Pawlaczyk et al. 2005). Szymańska's studies (2007) indicated that the Tisovik half-siblings varied least due to the shape of their hypodermic cells. A similar result was obtained in this study.

On the other hand, two of these traits - width of hypodermic cell and number of endodermic cells - were identified in this study as having the greatest impact on forming inter-progeny variability. Szymańska's studies indicated that the number of endodermic cells was the feature with the greatest impact on the variability between progeny. According to Szymanska (2007), the shape of the hypodermic cell was a trait which least differentiated progeny. This study indicated that the feature least differing progeny line was the width of the needle.

Based on analyses conducted both by Szymańska (2007) and in this paper, it is possible to comment on the highly significant variation between individuals within progeny and between progeny lines. This analysis in- dicates that the greatest diversity occurred in progeny line T1, and the lowest in T4. Our results overlap in many cases with Szymańska's results, suggesting that the large genetic diversity observed by Szymańska was preserved.

Comparing the results for the offspring with those for maternal trees showed that they were not the same traits that most differentiated progeny and maternal trees. The greatest impact on the variability of maternal trees was shown by morphological traits such as length, width and shape of the needle. In contrast, with offspring at the inter-progeny level, the largest impact was shown by anatomical features, like the width of hypodermic cells, number of endodermic cells and distance from vascular bundle to abaxial needle edge. However, similar morphological features as maternal trees differentiated individuals at the intra-progeny level.

Based on the analysis of arithmetic means for each trait, it can be stated that the progeny were characterized by a larger value of 5 of the 12 tested traits, both morphological and anatomical. Offspring had longer, but more flattened needles, wider hypodermic cells, more endoderm cells around the vascular bundle, a greater distance from vascular bundle to abaxial needle edge and more flattened hypodermic cells than maternal trees.

The calculated correlation coefficients indicate a very low correlation between the values of the characteristics of parents and offspring. Only the distance from resin canals to vascular bundle in the offspring grew with the increase of this characteristic in maternal trees.

Comparing traits for particular progeny lines and their maternal trees indicates that all progeny lines and their maternal trees differed highly statistically significantly in terms of the height and shape of the needle, distance from vascular bundle to abaxial needle edge and distances from resin canals to vascular bundle. This result confirmed that the needles of young trees had a flatter shape than those of adult trees. The smallest differences between offspring and maternal trees were in the height and width of the hypodermic cell, the diameter of resin canals and the number of endodermic cells. These features were the most stable and the age of trees did not affect the trait size. Hence, these traits can be considered the most reliable when comparing trees of different ages.

\subsection{Molecular analysis}

The first molecular analyses on this population were carried out in terms of isozyme polymorphism by Mejnartowicz (1996) and Goncharenko \& Savitsky (2000). They found that this population was characterized by a smaller number of alleles per locus and a much smaller percentage of polymorphic loci than 
other populations of silver fir. This population was characterized by an excess of heterozygotes, which was the result of a long period of selection and adaptation to rapidly changing environmental conditions in the Białowieża Primeval Forest after the last period of glaciation.

The first studies of the polymorphism of microsatellite chloroplast DNA in Abies alba were carried out by Ziegenhagen \& Vendramin (1997), Ziegenhagen et al. (1998) and Vendramin et al. (1999). Those studies were based on two chloroplast microsatellite loci Pt 30204 and Pt 71936. Ziegenhagen \& Vendramin (1997) studied seven European silver fir populations and found that both loci were highly polymorphic. In combination, they allowed the detection of 36 different haplotypes. In the paper by Vendramin et al. (1999), 17 populations of fir were analyzed - from three populations from France, Germany and Croatia; from two from Italy and Poland; and one from Romania, Bulgaria, Switzerland and Spain - distributed all over a natural range. They found eight and 18 different length variants at the studied loci, which combined into 90 different haplotypes. Genetic distances between most populations were high and significant. They also gave evidence to the spatial organization of the distribution of haplotypes, as shown by permutation tests, which demonstrated that genetic distances increased with spatial distances. A large heterogeneity in the levels of diversity across populations was observed.

The studies presented in this paper refer to the results of four loci, two of them were analyzed in papers mentioned above. Progeny and maternal trees from the Tisovik Reserve have a similar level of haplotypic variation to two Polish populations from Jata and Minsk Mazowiecki described by Vendramin et al. (1999); similar to most populations from Central Europe (Germany and France) - about 0.94. In Tisovik progeny, we detected (for 4 loci) 107 different haplotypes, while in the Vendramin et al. (1999) paper (for two loci), there were 90 different haplotypes. However, in the population from Tisovik, we found about 4 alleles per locus (allelic diversity about 0.6 ), whereas in other populations from Central Europe, there were about 7 alleles per locus. This conclusion confirms the data for progeny of populations from dense ranges of silver fir (allelic diversity about 0.8) (Pawlaczyk et al. unpublished).

AMOVA calculated in progeny indicated that all diversity was within progeny lines, so we did not discover differentiation among progeny lines. It confirms the hypothesis that there is no correlated mating in fir and probably maternal trees are pollinated by pollen from the different parental trees with the similar frequency.

The discovered level of genetic variation in progeny $\left(H_{H}=0.954\right)$, and in maternal trees $\left(H_{H}=0.936\right)$, was similar. However, in progeny, we detected a greater number of different haplotypes than in maternal trees. In progeny, 107 haplotypes in 274 trees were discovered. Only nine in 40 trees were the same like in maternal trees, which means that 98 haplotypes in 234 trees were pollen immigration from trees from other stands. Probably firs from Tisovik may be pollinated by trees from artificial population growing in the Polish part of Białowieża Primeval Forest as postulated by Pawlaczyk et al. (2017). There are several stands established in 1920s and 1930s, where seedlings of silver fir of unknown origin were planted (Mejnartowicz 1996a, 1996b; Korczyk et al. 1997). Moreover, it is suggested that in this area not only Abies alba but other species or hybrid species from the Abies genus are growing, which may have pollinated Tisovik population. This thesis may confirm the dendrogram drawn for 107 detected haplotypes. Haplotypes created two main groups, and 9 maternal haplotypes, which occurred in progeny belonging to the same bigger groups. The second group was smaller and may consist of offspring of another Abies species. However, this hypothesis requires further analysis.

\section{Conclusion}

In progeny lines, the variability was higher than in maternal trees in both used markers. Comparison of morphological and molecular studies showed that both markers gave similar result and detected the highest diversity occurring in progeny line $\mathrm{T} 1$ (had the largest values for 5 anatomical needle features, the highest values of coefficients of variability and the highest number of detected different haplotypes). Other progeny lines exhibited medium levels of diversity, so such correlation was not noticeable.

Despite the detection of small variations in populations of maternal trees from Tisovik Reserve, it can be concluded that the offspring were characterized by a relatively high phenotypic and genetic diversity, which may be a result of additions of gene pool by pollen from other stands of silver fir.

Acknowledgments. The authors wish to thank Prof. A. F. Korczyk from the Forest Research Institute in Białowieża and Bialystok University of Technology for providing the plant material for study. This work was supported by the National Science Centre in Poland under Grant number NN 305373938 . 


\section{References}

BŁocka A. \& Staszewski T. 2007. Fluctuating asymmetry of needles as a non-specific stress indicator of Scots Pine (Pinus sylvestris L.). Forest Research Papers 4: 125-131 (in Polish).

Clark C. M., Wentworth T. R. \& O’malley D. M. 2000. Genetic Discontinuity Revealed by Chloroplast Microsatellites in Eastern North American Abies (Pinaceae). Am. J. Bot. 87: 774-782.

Chudzińska E., Pawlaczyk E. M., Celiński K. \& Diatta J. B. 2014. Response of Scots pine (Pinus sylvestris L.) to stress induced by different types of pollutants testing the fluctuating asymmetry. Water Environ J. 28(4): 533-539.

Chudzińska E., Celiński K., Pawlaczyk E. M, Wojnicka-PóŁtorak A. \& Diatta J. B. 2016. Trace element contamination differentiates the natural population of Scots pine: evidence from DNA microsatellites and needle morphology. Environ. Sci. Pollut. R. 23(21): 22151-22162.

Doyle J. J. \& Doyle J. L. 1990. Isolation of plant DNA from fresh tissue. Focus 12: 13-15.

Dzialuk A., Muchewicz E., Boratyński A., Montserrat, BoRATYŃSKA K. \& BURCZYK J. 2009. Genetic variation of Pinus uncinata (Pinaceae) in the Pyrenees determined with cpSSR markers. Plant Syst. Evol. 277: 197-205.

Echt C. S., Deverno L. L., Anzidei M. \& Vendramin G. G. 1998. Chloroplast Microsatellites Reveal Population Genetic Diversity in Red Pine, Pinus resinosa Ait. Mol. Ecol. 7: 307-316.

Excoffier L., Laval G. \& Schneider S. 2005. Arlequin ver. 3.0: An integrated software package for population genetics data analysis. Evolutionary Bioinformatics Online 1: 47-50.

Goncharenko G. G. \& Savitsky B. P. 2000. Population and genetic resources of silver fir in Belarus. 121 pp. National Academy of Science of Belarus, Forest Institute, Gomel.

Gömöry D., Longauer R., Liepelt S., Ballian D., Brus R., Kraigher H., Parpan V. I., Parpan T. V., Paule L., Stupar V. \& Ziegenhagen B. 2004. Variation patterns of mitochondrial DNA of Abies alba Mill. in suture zones of postglacial migration in Europe. Acta Soc. Bot. Pol. 73: 203-206.

GosTyŃSKA-JAKUSZEWSKA M. 1972. European silver fir ( $A b$ ies alba Mill.) In: K. Browicz (ed.). Atlas of species distribution of trees and shrubs in Poland, 12, pp. 5-10. Polish Scientific Publishers PWN, Warszawa-Poznań (in Polish).

GóRSKI S. 1829. O roślinach żubrom upodobanych, jako też innych w puszczy Białowiezkiey. Dziennik Wileński 9: 207-217.

InNes J. L. \& Skelly J. M. 2002. Forest decline and air pollution: an assessment of 'forest health' in the forests of Europe, the Northeastern United States, and Southeastern Canada. In: J. N. B. Bell \& M. Treshow (eds.). Air pollution and plant life. 2nd edition, pp. 273-294. John Wiley, London.
Klánowá J., Čupr P., Baráková D., Šeda Z., Anděl P. \& Holoubek I. 2009. Can pine needles indicate trends in the air pollution levels at remote sites? Environ. Pollut. 157: 3248-3254.

Konnert M. \& Bergmann F. 1995. The geographical distribution of genetic variation of silver fir (Abies alba, Pinaceae) in relation to its migration history. Plant Syst. Evol. 195: 19-30.

KorCzyK A. F. 1999. Estimation of genetic and breeding value of natural populations of silver fir (Abies alba Mill.) from the eastern species range in Poland. Publishing House of the University of Agriculture in Krakow. Scientific Papers 61: 155-170 (in Polish).

Korczyk A. F. 2015a. The "Tisovik" reserve of Silver fir in the Belarusian national park "Belavezhskaya Pushcha". Forest Research Papers 76(1): 18-36.

KorCZYK A. F. 2015b. The ancestral conservative tillage of silver fir in the "Tisovik" reserve of the Białowieża Primeval Forest. Forest Research Papers 76(2): 153167.

Korczyk A. F., Kawecka A., Martysevič V. V. \& Strelkov A. Z. 1997. Natural stand of silver fir (Abies alba Mill.) in Białowieża Primeval Forest Papers of Forest Research Institute series A, 837: 27-62 (in Polish).

Kozlov M. V. \& Niemelä P. 1999. Difference in needle length - a new and objective indicator of pollution impact on Scots pine (Pinus sylvestris). Water Air Soil Poll. 116: 365-370.

Kral F. 1980. Waldgeschichtliche Grundlagen für die Ausscheidung von Ökotypen bei Abies alba. Proceedings 3 . 158-168 pp. IUFRO Tannensymposium Wien. Österr. Agrar-Verlag, Vienna.

Liepelt S., Bialozyt R. \& Ziegenhagen B. 2002. Winddispered pollen mediates postglacial gene flow among refugia. PNAS USA 99: 14590-14594.

Liepelt S., Cheddadi R., De Beaulieu J.-L., Fady B., Gömöry D., Hussendörfer E., Konnert M., Litt T., Longauer R., Terhürne-Berson R. \& Ziegenhagen B. 2009. Postglacial range expansion and its genetic imprints in Abies alba (Mill.) - A synthesis from paleobotanic and genetic data. Rev. Palaeobot. Palyno. 153: 139-149.

Mejnartowicz L. 1996. Origin of silver fir stands in Białowieża Primeval Forest. In: P. PAschaslis \& S. ZajĄCZKOWSKI (eds.). Biodiversity Protection of Białowieża Primeval Forest, pp. 35-50. Warszawa.

Morgante M., Felice N. \& Vendramin G. G. 1997. Analysis of Hypervariable Chloroplast Microsatellite in Pinus halepensis Reveal a Dramatic Bottleneck. In: A. KARP, P. G. IsaAc \& D. S. Ingram (eds.). Molecular Tools for Screening Biodiversity: Plants and Animals, pp. 402-412. Chapman and Hall, London.

Neale D. B. \& Sederoff R. R. 1989. Paternal Inheritance of Chloroplast DNA and Maternal Inheritance of Mitochondrial DNA in Loblolly Pine. Theor. Appl. Genet. 77: 212-216.

NeI M. 1972. Genetic distance between populations. Amer. Natur. 106: 283-292. 
Parfenov V. I. \& SavchuK S. S. 2015. Abies alba Mill. In: I. M. Kachanovskiy, M. Ye. Nikiforov, V. I. Parfenov, O. I. Borodin, A. V. Pugachevskiy, V. M. Baychorov, O. S. Gapiyenko, A. S. Giryachev \& T. P. Yevdaseva (eds.). 2015. Krasnaya kniga Respubliki Belarus, rasteniya: redkiye i nakhodyashchiyesya pod ugrozoy ischeznoveniya vidy dikorastushchikh rasteniy, 4. ed., 25-26 pp. Belaruskaya Entsyklapedyya imya P. Broy̆ki, Minsk, (in Russian).

Pawlaczyk E. M. \& Bobowicz M. A. 2008a. Silver fir (Abies alba Mill.) differentiation from Jata Reserve as expressed by morphological and anatomical features of needles Forest Research Papers 69: 243-253 (in Polish).

Pawlaczyk E. M. \& Bobowicz M. A. 2008b. Międzyrodowe zróżnicowanie jodły pospolitej (Abies alba Mill.) z Rezerwatu "Kamienna Góra” z Roztoczańskiego Parku Narodowego z uprawy doświadczalnej wyrażone $\mathrm{w}$ cechach morfologii i anatomii igieł. In: K. Kannenberg \& H. Szramka (eds.). Management of Environmental Protection in Forests, 2, pp. 3846. Higher School of Environmental Management, Tuchola.

Pawlaczyk E. M., Bobowicz M. A. \& Korczyk A. F. 2002. Variability of three populations of Abies alba Mill. expressed in morphological and anatomical needle traits. Ecological Questions 2: 25-32.

Pawlaczyk E. M., Bobowicz M. A. \& Lesiczka P. 2010. Genetic differentiation of four progeny of silver fir (Abies alba Mill.) from Tisovik Reserve from experimental culture in Hajnówka District expressed in morphology and anatomy of needles traits. Management of Environmental Protection in Forests 4: 120-138 (in Polish).

Pawlaczyk E. M., Grzebyta J., Bobowicz M. A. \& Korczyk A. F. 2005. Individual differentiation of Abies alba Mill. population from the "Tisovik" Reserve. Variability expressed in morphology and anatomy of needles. Acta Biol. Cracov. Bot. 47: 137-144.

Pawlaczyk E. M., Kroplewska I. \& Bobowicz M. A. 2013. Postglacial migration of silver fir (Abies alba Mill.) to Poland - analysis on the basis of mitochondrial DNA polymorphism. Sylwan 157: 458-463 (in Polish).

Pawlaczyk E. M., Bączkiewicz A., Buczkowska K. \& BoBowicz M. A. 2017. Genetic variation of silver fir progeny from Tisovik Reserve population determined via microsatellite and isozyme markers. Folia For.
Pol. Series A Forestry 59(1): 45-58, DOI: 10.1515/ ffp-2017-00051

Peakall R. \& Smouse P. E. 2006. GenAlEX 6: genetic analysis in Excel. Population genetic software for teaching and research. Mol. Ecol. Notes 6: 288-295.

Provan J., Soranzo N., Wilson N. J., Mcnicol J. W., Forrest G. I., Cottrell J. \& Powell W. 1998. Gene-pool variation in Caledonian and European Scots pine (Pinus sylvestris L.) revealed by chloroplast simple-sequence repeats. P. Roy. Soc. Lond. B. Bio. 265: 1697-1705.

Semerikova S. A. \& Semerikov V. L. 2007. The diversity of chloroplast microsatellite loci in siberian fir (Abies sibirica Ledeb.) and two far east fir species A. nephrolepis (Trautv.) Maxim. and A. sachalinensis. Russ. J. Genet. 43: 1373-1381.

SzymańsKa M. 2007. Genetyczna zmienność potomstwa jodły pospolitej Abies alba Mill. z rezerwatu Tisovik w uprawie testowej oszacowana za pomoca cech morfologii i anatomii igieł. $\mathrm{Ph}$. D. Thesis, Adam Mickiewicz University, Poznań, Poland.

Vendramin G. G., Degen B., Petit R. J., Anzidei M., Madaghiele A. \& Ziegenhagen B. 1999. High level of variation at Abies alba chloroplast microsatellite loci in Europe. Mol. Ecol. 8: 1117-1126.

Vendramin G. G., Lelli L., Rossi P. \& Morgante M. 1996. A set of primers for the amplification of 20 chloroplast microsatellites in Pinaceae. Mol. Ecol. Notes 5: 111-114.

Vendramin G. G. \& Ziegenhagen B. 1997. Characterization and inheritance of polymorphic plastid microsatellites in Abies. Genome 40: 857-864.

Wright J. W. 1976. Introduction to Forest Genetics. 463 pp. Academic Press, New York.

Yeh F. C., Yang R. \& Boyle T. 1999. PopGen 1.0. http:// cc.oulu.fi/ jaspi/popgen/popgen.htm

ZaJĄC A. \& ZaJĄC M. (eds.). 2001. Distribution Atlas of Vascular Plants in Poland. xii+714 pp. Edited by Laboratory of Computer Chorology, Institute of Botany, Jagiellonian University, Cracow.

Ziegenhagen B., Fady B., Kuhlenkamp V. \& Liepelt S. 2005. Differentiating groups of Abies species with a simple molecular marker. Silvae Genet. 54: 123-126.

Ziegenhagen B., Scholz F., Madaghiele A. \& Vendramin G. G. 1998. Hypervariable chloroplast microsatellites as markers for paternity analysis in Abies alba. Can. J. Forest. Res. 28: 317-321. 
Appendix 1. The list of detected haplotypes in progeny lines of Abies alba

\begin{tabular}{|c|c|c|c|c|c|c|c|}
\hline $\begin{array}{l}\text { Order } \\
\text { number }\end{array}$ & Haplotype & Number & Progeny lines & $\begin{array}{l}\text { Order } \\
\text { number }\end{array}$ & Haplotype & Number & Progeny lines \\
\hline 1 & $94 / 107 / 133 / 144$ & 1 & T17 & 55 & $95 / 111 / 135 / 147$ & 2 & T9, T12 \\
\hline 2 & $94 / 109 / 139 / 143$ & 1 & $\mathrm{~T} 3$ & 56 & $95 / 111 / 137 / 144$ & 1 & T11 \\
\hline 3 & $94 / 111 / 139 / 146$ & 1 & $\mathrm{~T} 13$ & 57 & $95 / 111 / 139 / 145$ & 1 & $\mathrm{~T} 2$ \\
\hline 4 & $94 / 112 / 144 / 147$ & 1 & $\mathrm{~T} 1$ & 58 & $95 / 111 / 141 / 145$ & 1 & $\mathrm{~T} 1$ \\
\hline 5 & $95 / 107 / 130 / 145$ & 1 & $\mathrm{~T} 1$ & 59 & $95 / 111 / 142 / 143$ & 1 & $\mathrm{~T} 2$ \\
\hline 6 & $95 / 107 / 132 / 148$ & 1 & $\mathrm{~T} 5$ & 60 & $95 / 111 / 142 / 145$ & 2 & T3, T12 \\
\hline 7 & $95 / 107 / 133 / 144$ & 1 & $\mathrm{~T} 17$ & 61 & $95 / 112 / 130 / 148$ & 3 & $\mathrm{~T} 1, \mathrm{~T} 16, \mathrm{~T} 17$ \\
\hline 8 & $95 / 108 / 131 / 143$ & 3 & T9 & 62 & $95 / 112 / 131 / 145$ & 1 & $\mathrm{~T} 5$ \\
\hline 9 & $95 / 108 / 131 / 144$ & 1 & T9 & 63 & $95 / 112 / 131 / 148$ & 15 & $\begin{array}{c}\text { T1, T6, T8, T9, } \\
\text { T11(2), T12, } \\
\text { T15(4), T16, T18, } \\
\text { T29(2) }\end{array}$ \\
\hline 10 & $95 / 108 / 133 / 144$ & 2 & $\mathrm{~T} 21$ & 64 & $95 / 112 / 131 / 149$ & 2 & $\mathrm{~T} 15, \mathrm{~T} 23$ \\
\hline 11 & $95 / 108 / 133 / 145$ & 1 & $\mathrm{~T} 18$ & 65 & $95 / 112 / 132 / 144$ & 2 & $\mathrm{~T} 12(2)$ \\
\hline 12 & $95 / 108 / 139 / 143$ & 1 & $\mathrm{~T} 15$ & 66 & $95 / 112 / 132 / 148$ & 2 & T18, T29 \\
\hline 13 & $95 / 108 / 139 / 144$ & 3 & $\mathrm{~T} 11, \mathrm{~T} 17, \mathrm{~T} 22$ & 67 & $95 / 112 / 132 / 149$ & 2 & $\mathrm{~T} 18, \mathrm{~T} 29$ \\
\hline 14 & $95 / 109 / 130 / 144$ & 1 & $\mathrm{~T} 21$ & 68 & $95 / 112 / 139 / 143$ & 1 & $\mathrm{~T} 15$ \\
\hline 15 & $95 / 109 / 130 / 148$ & 1 & $\mathrm{~T} 1$ & 69 & $95 / 112 / 142 / 148$ & 1 & $\mathrm{~T} 15$ \\
\hline 16 & $95 / 109 / 131 / 144$ & 2 & $\mathrm{~T} 18, \mathrm{~T} 23$ & 70 & $95 / 112 / 145 / 146$ & 1 & $\mathrm{~T} 1$ \\
\hline 17 & $95 / 109 / 132 / 144$ & 14 & $\begin{array}{c}\text { T3, T4(3), T6, } \\
\text { T8(2), T11, } \\
\text { T12(2), T13, } \\
\text { T16, T17, T22 }\end{array}$ & 71 & $95 / 113 / 130 / 148$ & 1 & T5 \\
\hline 18 & $95 / 109 / 132 / 145$ & 14 & $\begin{array}{c}\mathrm{T} 3(3), \mathrm{T} 4(2), \\
\mathrm{T} 6, \mathrm{~T} 8, \mathrm{~T} 9, \\
\mathrm{~T} 12, \mathrm{~T} 13, \\
\mathrm{~T} 16(2), \mathrm{T} 17, \\
\mathrm{~T} 18\end{array}$ & 72 & $95 / 113 / 131 / 145$ & 1 & T6 \\
\hline 19 & $95 / 109 / 133 / 142$ & 1 & $\mathrm{~T} 4$ & 73 & $95 / 113 / 131 / 147$ & 2 & $\mathrm{~T} 16(2)$ \\
\hline 20 & $95 / 109 / 133 / 143$ & 1 & $\mathrm{~T} 2$ & 74 & $95 / 113 / 131 / 148$ & 11 & $\begin{array}{c}\text { T6, T8, T9(3), } \\
\text { T11(2), T13(2), } \\
\text { T16, 34T17 }\end{array}$ \\
\hline 21 & $95 / 109 / 133 / 144$ & 17 & $\begin{array}{c}\text { T5, T6(2), T8, } \\
\text { T13, T17(2), } \\
\text { T18(3), T21, } \\
\text { T22(3), T23, } \\
\text { T29(2) }\end{array}$ & 75 & $95 / 113 / 131 / 149$ & 3 & $\mathrm{~T} 235(2), \mathrm{T} 18$ \\
\hline 22 & $95 / 109 / 133 / 145$ & 16 & $\begin{array}{l}\text { T2, T3, T4, } \\
\text { T5, T8, T16, } \\
\text { T17, T18(3), } \\
\text { T21, T29(5) }\end{array}$ & 76 & $95 / 113 / 132 / 148$ & 1 & $\mathrm{~T} 13$ \\
\hline 23 & $95 / 109 / 133 / 147$ & 1 & T17 & 77 & $95 / 113 / 132 / 149$ & 1 & $\mathrm{~T} 22$ \\
\hline 24 & $95 / 109 / 133 / 148$ & 1 & $\mathrm{~T} 23$ & 78 & $95 / 113 / 138 / 148$ & 1 & $\mathrm{~T} 23$ \\
\hline 25 & $95 / 109 / 134 / 144$ & 1 & T6 & 79 & $95 / 113 / 142 / 148$ & 1 & $\mathrm{~T} 21$ \\
\hline 26 & $95 / 109 / 134 / 145$ & 1 & T6 & 80 & $96 / 109 / 130 / 148$ & 1 & $\mathrm{~T} 5$ \\
\hline 27 & $95 / 109 / 138 / 145$ & 1 & $\mathrm{~T} 4$ & 81 & $96 / 109 / 131 / 145$ & 1 & $\mathrm{~T} 2$ \\
\hline 28 & $95 / 109 / 138 / 148$ & 1 & $\mathrm{~T} 2$ & 82 & $96 / 109 / 132 / 143$ & 1 & $\mathrm{~T} 5$ \\
\hline 29 & $95 / 109 / 140 / 144$ & 1 & $\mathrm{~T} 13$ & 83 & $96 / 109 / 132 / 144$ & 1 & T5 \\
\hline 30 & $95 / 109 / 142 / 145$ & 3 & $\mathrm{~T} 13, \mathrm{~T} 21(2)$ & 84 & $96 / 109 / 132 / 145$ & 2 & T8, T16 \\
\hline 31 & $95 / 110 / 130 / 145$ & 1 & $\mathrm{~T} 6$ & 85 & $96 / 109 / 132 / 146$ & 1 & T16 \\
\hline 32 & $95 / 110 / 130 / 146$ & 1 & $\mathrm{~T} 15$ & 86 & $96 / 109 / 133 / 143$ & 1 & T6 \\
\hline 33 & $95 / 110 / 131 / 146$ & 3 & $\mathrm{~T} 1, \mathrm{~T} 2, \mathrm{~T} 17$ & 87 & $96 / 109 / 133 / 144$ & 3 & $\mathrm{~T} 4, \mathrm{~T} 18, \mathrm{~T} 21$ \\
\hline 34 & $95 / 110 / 132 / 145$ & 1 & $\mathrm{~T} 1$ & 88 & $96 / 109 / 133 / 145$ & 1 & $\mathrm{~T} 22$ \\
\hline 35 & $95 / 110 / 133 / 144$ & 1 & $\mathrm{~T} 11$ & 89 & $96 / 109 / 139 / 140$ & 1 & $\mathrm{~T} 11$ \\
\hline 36 & $95 / 110 / 133 / 145$ & 1 & T13 & 90 & $96 / 110 / 139 / 145$ & 1 & $\mathrm{~T} 17$ \\
\hline 37 & $95 / 110 / 133 / 146$ & 2 & T13, T29 & 91 & $96 / 110 / 139 / 146$ & 1 & $\mathrm{~T} 8$ \\
\hline 38 & $95 / 110 / 136 / 141$ & 1 & $\mathrm{~T} 1$ & 92 & $96 / 110 / 142 / 145$ & 2 & T5, T12 \\
\hline 39 & $95 / 110 / 136 / 148$ & 1 & $\mathrm{~T} 2$ & 93 & $96 / 110 / 142 / 146$ & 3 & T2, T21, T29 \\
\hline 40 & $95 / 110 / 139 / 144$ & 2 & $\mathrm{~T} 5, \mathrm{~T} 23$ & 94 & $96 / 110 / 145 / 148$ & 1 & $\mathrm{~T} 1$ \\
\hline
\end{tabular}




\begin{tabular}{|c|c|c|c|c|c|c|c|}
\hline $\begin{array}{l}\text { Order } \\
\text { number }\end{array}$ & Haplotype & Number & Progeny lines & $\begin{array}{l}\text { Order } \\
\text { number }\end{array}$ & Haplotype & Number & Progeny lines \\
\hline 41 & $95 / 110 / 139 / 145$ & 8 & $\begin{array}{c}\text { T4(4), T12, } \\
\text { T13, T21, T23 }\end{array}$ & 95 & $96 / 111 / 131 / 147$ & 1 & $\mathrm{~T} 2$ \\
\hline 42 & $95 / 110 / 139 / 146$ & 5 & $\begin{array}{c}\text { T3, T4, } \\
\text { T16(2), T22 }\end{array}$ & 96 & $96 / 112 / 130 / 143$ & 1 & $\mathrm{~T} 1$ \\
\hline 43 & $95 / 110 / 139 / 147$ & 1 & $\mathrm{~T} 15$ & 97 & $96 / 112 / 130 / 147$ & 1 & T6 \\
\hline 44 & $95 / 110 / 141 / 144$ & 1 & $\mathrm{~T} 22$ & 98 & $96 / 112 / 130 / 148$ & 2 & $\mathrm{~T} 3(2)$ \\
\hline 45 & $95 / 110 / 141 / 145$ & 6 & $\begin{array}{c}\mathrm{T} 2, \mathrm{~T} 3, \mathrm{~T} 5(2), \\
\mathrm{T} 8, \mathrm{~T} 11\end{array}$ & 99 & $96 / 112 / 131 / 143$ & 1 & $\mathrm{~T} 16$ \\
\hline 46 & $95 / 110 / 141 / 146$ & 11 & $\begin{array}{l}\mathrm{T} 2(2), \mathrm{T} 3(4) \\
\mathrm{T} 5, \mathrm{~T} 8, \mathrm{~T} 11, \\
\text { T15, T16 }\end{array}$ & 100 & $96 / 112 / 131 / 147$ & 1 & $\mathrm{~T} 22$ \\
\hline 47 & $95 / 110 / 142 / 142$ & 1 & $\mathrm{~T} 4$ & 101 & $96 / 112 / 131 / 148$ & 6 & $\begin{array}{c}\mathrm{T} 9(3), \mathrm{T} 17(2), \\
\mathrm{T} 22\end{array}$ \\
\hline 48 & $95 / 110 / 142 / 143$ & 1 & $\mathrm{~T} 15$ & 102 & $96 / 112 / 132 / 148$ & 1 & $\mathrm{~T} 23$ \\
\hline 49 & $95 / 110 / 142 / 144$ & 1 & T13 & 103 & $96 / 112 / 132 / 149$ & 1 & $\mathrm{~T} 1$ \\
\hline 50 & $95 / 110 / 142 / 145$ & 14 & $\begin{array}{c}\mathrm{T} 6(3), \mathrm{T} 8(2), \\
\mathrm{T} 12(2), \mathrm{T} 13, \\
\mathrm{~T} 15(2), \\
\mathrm{T} 21(2), \mathrm{T} 22, \\
\mathrm{~T} 29\end{array}$ & 104 & $96 / 112 / 134 / 148$ & 1 & $\mathrm{~T} 29$ \\
\hline 51 & $95 / 110 / 142 / 146$ & 13 & $\begin{array}{c}\text { T5, T8, } \\
\text { T11(4), } \\
\text { T12(2), T15, } \\
\text { T18, T22(3) }\end{array}$ & 105 & $96 / 112 / 142 / 146$ & 1 & T5 \\
\hline 52 & $95 / 111 / 131 / 148$ & 1 & $\mathrm{~T} 12$ & 106 & $96 / 112 / 144 / 144$ & 1 & $\mathrm{~T} 1$ \\
\hline 53 & $95 / 111 / 133 / 144$ & 1 & $\mathrm{~T} 13$ & 107 & $97 / 112 / 131 / 148$ & 1 & T9 \\
\hline 54 & $95 / 111 / 135 / 146$ & 1 & T9 & & & & \\
\hline
\end{tabular}

